\title{
最近の歯学
}

\section{4. 口腔解剖}

BrdU を用いた下顎頭における軟骨細胞の増殖および位置的変化についての観察

\author{
東京医科歯科大学歯学部口腔解剖学第 2 講座 馬場 麻人, 寺島 達夫 \\ 東京医科歯科大学歯学部门腔解剖学第 1 講座 山下 靖雄
}

これまで DNA 合成能や細胞分裂能を検索する研究 法として, ${ }^{3} \mathrm{H}$-thymidineが用いられてきた。しかし長 時間を要することに加え，放射性物質であることが大 きな欠点であった。一方，近年利用されるようになっ た BrdU (5-bromo-2'deoxy-uridine) を用い細胞增殖 を検出する方法は，細胞の DNA 合成期に扮いて DNA 鎖内の thymidineの位置にBrdU が取り込まれ ることを利用し，DNAに取り込まれたBrdUを免疫 組織化学的に観察L DNA 合成能や細胞分裂能を検索 する方法である。この方法では所要時間がかなり短縮 され，放射性物質を扱う制約もなく，その検出感度に おいても ${ }^{3} \mathrm{H}$-thymidine と同等であるといわれてお $\eta$, 脱灰などの大量の廃液が出る過程を必要とする硬 組織における研究において有効な手段であると思われ る。

筆者らのグループは、下顎頭軟骨における軟骨細胞 の動態を知ることを目的とし 2 週跉ラットに BrdU を腹注により投与し，免疫組織化学的に下顎頭軟骨で の BrdUのラベルの経時変化を観察している。この実 験系においては，投与時にDNA 合成が行われている 細胞，すなわち増殖能のある細胞の核には BrdU が取 り込まれる。下顎頭軟骨の中央部では, BrdUの取り込 みを示すラベルは，投与 3 時間後で骨軟骨プロゲニ夕 層で観察され，また下顎頭表層の線維層の細胞あるい は関節円板表層の細胞にもそれは認められる。3 日後 ではさらにラベルの観察される領域は BrdUを取り 込んでいる細胞の分裂と位置的変化のため広がって, 軟骨細胞の分化方向に軟骨芽細胞層でもラベルが観察 された。5 日後では，骨軟骨プロゲニ夕層でのラベル は減少するが，さらに分化の進んだ肥大軟骨細胞層に までラベルされた細胞が観察され，7 日後では軟骨細 胞の開放部位にラベルが認められた。

以上より，投与時に下顎頭軟骨の增殖層の $\mathrm{BrdU}$ を 取り込んだ細胞は分裂をくり返し，増殖層にとどまる 細胞と肥大軟骨細胞方向へと分化し, 細胞周囲に基質 を分泌することにより相対的な位置を変化させていく 細胞が存在することが示されている。また, 肥大軟骨
細胞まで分化が進行するのに要する時間は $5 \sim 7$ 日程 度であり, その時点でも BrdU は代謝されないで抗体 によって検出される程度の量は存在している。そして, 下顎頭軟骨組織では，ラベルされた軟骨細胞の分化速 度は一定ではないことも判明した。

このように BrdU ラベリング法により，軟骨細胞の 分化の過程の検索を行うことができ，今後も投与条件 をさまざまに設定することにより新たな知見を得るこ とが期待される。

\section{文献}

1) Apte, S. S. : Histochem. J. $22:$ 401-408, 1990.

2）馬場麻人, 寺島達夫, 山下靖雄：口病誌 $62: 164$, 1995.

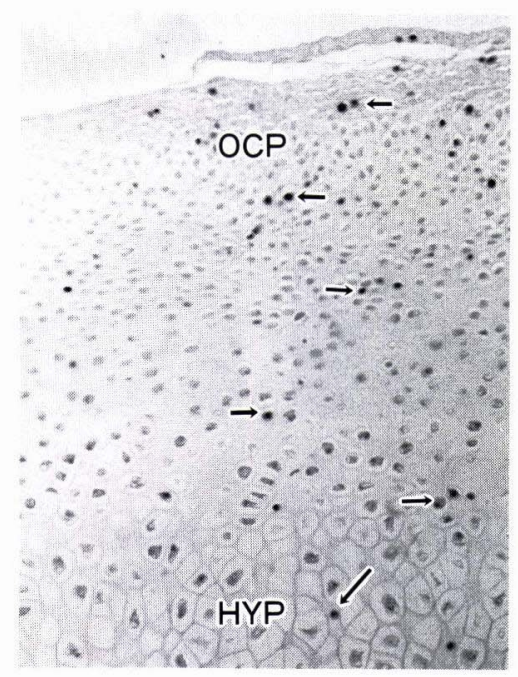

図 12 週齢ラットに $\operatorname{BrdU}$ 投与後 1 週間後の下顎 頭中央部に扮ける軟骨細胞の BrdU 取り込みを 示す免疫染色像。骨軟骨プロゲニタ層 (OCP) か ら写真下方の肥大軟骨細胞層 (HYP) の広い範囲 でBrdUの取り込み $(\rightarrow)$ が認められ，時間とと もに分裂した細胞が分化し基質形成を行いなが ら，位置を変化させていることが示唆される 